\title{
Management of Attitude Assessment, Knowledge and Skills-Based on the 2013 Curriculum
}

\author{
Sarkadi \\ Department of Pancasila and Citizenship Education \\ Universitas Negeri Jakarta, Indonesia \\ sarkadi@unj.ac.id
}

\author{
Asep Rudi Casmana \\ Department of Pancasila and Citizenship Education \\ Universitas Negeri Jakarta, Indonesia \\ aseprudi@unj.ac.id
}

\begin{abstract}
The long-term goal of this study is for PPKN teachers in DKI Jakarta to assess their attitudes, knowledge and skills correctly and adequately. While the specific purpose is to get information about how to assess the attitudes, knowledge and skills carried out by PPKn teachers in DKI Jakarta. It is to know whether the appraisal management been done correctly. So the value received by students is indeed a real value, not just a written value. This research was conducted by distributing a questionnaire management assessment of attitudes, knowledge, and skills starting from the planning of assessment, implementation of assessment, and processing of value. A questionnaire statement is made in the form of a positive statement, so that if the teacher answer "done" it means that the management of the assessment is in accordance with the statement. The results showed that of the 45 PPKn teachers who were made as respondents in the planning stage as much as $84 \%$ did the assessment planning, while $16 \%$ did not do assessment planning. In the implementation phase of the 45 respondents, $81 \%$ of PPKn teachers conducted assessment planning, and as many as $19 \%$ did not carry out assessment planning. At the processing stage, $72 \%$ of PPKn teachers do value processing, while $28 \%$ do not process value.
\end{abstract}

Keywords: management, assessment, attitude, knowledge, skills

\section{INTRODUCTION}

At the beginning of the 2013 curriculum, schools received pros and cons. Some consider the 2013 curriculum to be good enough to be implemented in schools, but there are also some teachers who find it difficult to implement the 2013 curriculum. For those who consider it good enough to apply the 2013 curriculum, it is because the 2013 curriculum is a student-based curriculum. The curriculum based on students in their learning provides freedom for students to move. They are of the view that the 2013 curriculum applied in schools can stimulate students to be creative and innovative in conducting classroom learning. This view is in line with the learning approach that adheres to student-centred learning (learner-centred education).

Meanwhile for some other teachers, the implementation of the 2013 curriculum is quite tricky, especially for teachers who teach in remote areas that do not have adequate facilities. According to them, the 2013 curriculum is challenging to implement because of the limited facilities and infrastructure including the absence of electricity into the area. According to him, it is impossible for teachers to implement the 2013 curriculum while electricity has not been connected. The demand for the use of IT-based learning media according to them will not be fulfilled because of the limited available facilities.

Other difficulties often raised by teachers in schools when implementing the 2013 curriculum are related to the difficulty in assessing students' attitudes, knowledge, and skills. The teachers consider that the assessment of students is challenging because of a large number of assessment instruments filled in. According to them, the number of assessment instruments also adds to the complexity of teachers in conducting assessments.

This condition is supported by data from research that has been carried out such as research conducted by the Directorate of SMP Kemdikbud specifically on the implementation of training and preparation of RPP shows that training of teachers and principals can help them understand the 2013 curriculum. They poorly understand Their understanding of the Permendikbud $81 \mathrm{~A}$ and the trainer's understanding of the concept and implementation of the 2013 curriculum still lacks, especially in the assessment aspects.

Meanwhile, the results of the monitoring and evaluation also showed that the lesson plans made by the teachers did not reflect the scientific approach desired by the 2013 curriculum, and the assessment aspect became its difficulty for participants in participating in the training. So there needs to be special training on aspects of $5 \mathrm{M}$ assessment and implementation. Regarding students applying the 2013 curriculum shows that students know about the outline that in each subject they have to do 5M. However, according to the students, not all have applied the $5 \mathrm{M}$ in each subject. They have no learning difficulties and can be overcome with subject teachers without involving BP teachers. But students complained about the lack of books owned, (2013 Junior High School Curriculum Assistance Materials).

\section{METHODS}

The purpose of this study was to obtain data / information on how to assess the attitudes, knowledge and skills carried out by PPKn teachers in classroom learning. With the knowledge of data / information related to the management of teacher assessments that have been carried out so far, the research will provide benefits for the teachers in doing what good assessment management is. This research is descriptive research. This descriptive study wants to illustrate how the management of PPKn teacher assessment is useful for assessing attitudes, knowledge, and skills. 
Data collection techniques were carried out by distributing research questionnaires to be answered by respondents. The research instrument with answer choices is done or not done by the PPKn teacher. The research instrument is made in a positive statement so that the answer is done means the teacher is doing according to the statement. Conversely, if the statement is answered not done, it means that the teacher did not do it according to the statement. If the teacher chooses the choice, it means that the teacher has carried out assessment management in accordance with the statement.

On the contrary, if the teacher answers the choice of not doing, then the teacher has not carried out assessment management in accordance with the statement. Research steps: (1) collect information literature related to research; (2) making research instruments; (3) conduct preliminary assessments / observations; (4) carry out observations; (5) collecting documentation; (6) make data analysis; (7) make a research report; and (8) dissemination of research results

\section{RESULTS}

This research is a descriptive study, so the data obtained is described based on the statement items that have been prepared. The statement includes planning in conducting an assessment consisting of 11 statements, an implementation statement in conducting an assessment consisting of 6 statements, and a value processing statement consisting of 8 statements. Meanwhile, the number of respondents who were successfully met were 45 PPKn teachers. Description about the assessment management conducted by the teacher can be seen as below (Table 1).

Table 1

Teacher Assessment Management Data

\begin{tabular}{|c|c|c|c|}
\hline No & Statement & Do & Are not done \\
\hline \multicolumn{4}{|c|}{ PLANNING } \\
\hline 1 & Do mapping for one semester about when to assess students & 41 & 4 \\
\hline 2 & Mapping of assessments is carried out on all aspects of assessment (attitudes, knowledge, and skills) & 38 & 7 \\
\hline 3 & $\begin{array}{l}\text { An assessment instrument for attitudes, knowledge, and skills is planned from the beginning before learning } \\
\text { begins }\end{array}$ & 39 & 6 \\
\hline 4 & Prepare learner assessment formats for assessment of attitudes, knowledge and skills & 43 & 2 \\
\hline 5 & Prepare a list of names of students in each class & 40 & 5 \\
\hline 6 & Prepare an attitude assessment instrument that will be used for one semester & 40 & 5 \\
\hline 7 & $\begin{array}{l}\text { Knowledge assessment instruments (questions) are prepared after the teacher analyses the material that has } \\
\text { been submitted }\end{array}$ & 40 & 5 \\
\hline 8 & Make a question lattice first before the question is assembled (made) & 37 & 8 \\
\hline 9 & The question grid must reflect what competencies students must possess & 40 & 5 \\
\hline 10 & Questions are made based on the wishes of the teacher who teaches in the class & 25 & 20 \\
\hline 11 & Prepare skills assessment instruments that will be used for one semester & 34 & 11 \\
\hline \multicolumn{4}{|c|}{ IMPLEMENTATION } \\
\hline 12 & When learning to conduct an attitude assessment in accordance with a predetermined plan & 39 & 6 \\
\hline 13 & Assessment of attitudes using prepared attitude instruments & 45 & - \\
\hline 14 & Conduct knowledge assessment in accordance with predetermined planning & 45 & - \\
\hline 15 & Knowledge assessment uses pre-prepared questions & 40 & 5 \\
\hline 16 & Conduct skills assessments in accordance with predetermined planning & 43 & 2 \\
\hline 17 & Skill assessment uses a skill assessment instrument that has been prepared & 43 & 2 \\
\hline \multicolumn{4}{|c|}{ VALUE PROCESSING } \\
\hline 18 & Perform a score (correction) of the attitude assessment that has been done & 31 & 14 \\
\hline 19 & Scoring (correction) of the knowledge assessment (answer sheet) that has been done & 44 & 1 \\
\hline 20 & Perform a score (correction) of the assessment of skills that have been done & 40 & 5 \\
\hline 21 & Include a score of assessment of attitudes, knowledge, and skills into prepared formats & 40 & 5 \\
\hline 22 & Analyze attitudes assessment scores into attitudes values & 30 & 15 \\
\hline 23 & Analyze scores on knowledge assessment into knowledge values & 40 & 5 \\
\hline 24 & Analyze skills assessment scores into skill values & 28 & 17 \\
\hline 25 & Enter the values of attitudes, knowledge, and skills in the assessment format that has been prepared & 40 & 5 \\
\hline
\end{tabular}

From the data described above, it is necessary to discuss the statement items starting from the time of the planning of the assessment, the implementation of the research, and when processing the value. The discussion can be described below (Table 2). From the data in the assessment plan above can be explained as below (Table 2):

Statement 1 Do a mapping for one semester about when to assess students

The study showed that from 45 teachers studied as many as 41 people $(91 \%)$ conducted a mapping for one semester about when to evaluate students. Only four teachers (9\%) did not do mapping for one semester about when to evaluate students. This figure shows that most of the teachers have done mapping for one semester about when to assess students.

\section{Statement 2 Mapping of assessments is carried out on all aspects of assessment (attitudes, knowledge and skills)}

The results of the study showed that 38 teachers $(84 \%)$ conducted an assessment mapping conducted on all aspects of assessment (attitude assessment. Knowledge and skills). And only seven teachers $(16 \%)$ did not carry out mapping assessments carried out on all aspects of assessment (attitude assessment). 
Statement 3 The instrument of assessment of attitudes, knowledge, and skills is planned from the beginning before learning begins

From the results of the study showed that as many as $39(87 \%)$ teachers had carefully planned the preparation of instruments for assessing attitudes, knowledge and skills. And only six teachers (13\%) teachers did not prepare instruments for attitudes, knowledge and skills assessment.
Statement 4. Prepare student assessment formats for assessment of attitudes, knowledge and skills.

As for the statement, 43 teachers (96\%) prepared the assessment formats for students, both assessing attitudes, knowledge and skills. While two teachers $(4 \%)$ did not prepare formats for assessing attitudes, knowledge and skills. From these data shows that assessment management at the planning stage has been carried out by the teachers.

Table 2

Assessment Planning

\begin{tabular}{|c|c|c|c|c|c|}
\hline \multirow[t]{2}{*}{ No } & \multirow{2}{*}{ Statements } & \multicolumn{2}{|c|}{ Do } & \multicolumn{2}{|c|}{$\begin{array}{c}\text { Are not } \\
\text { done }\end{array}$} \\
\hline & & f & $\%$ & f & $\%$ \\
\hline 1 & Do mapping for one semester about when to assess students & 41 & 91 & 4 & 9 \\
\hline 2 & Mapping of assessments is carried out on all aspects of assessment (attitudes, knowledge, and skills) & 38 & 84 & 7 & 16 \\
\hline 3 & $\begin{array}{l}\text { An assessment instrument for attitudes, knowledge, and skills is planned from the beginning before learning } \\
\text { begins }\end{array}$ & 39 & 87 & 6 & 13 \\
\hline 4 & Prepare learner assessment formats for assessment of attitudes, knowledge and skills & 43 & 96 & 2 & 4 \\
\hline 5 & Prepare a list of names of students in each class & 40 & 89 & 5 & 11 \\
\hline 6 & Prepare an attitude assessment instrument that will be used for one semester & 40 & 89 & 5 & 11 \\
\hline 7 & $\begin{array}{l}\text { Knowledge assessment instruments (questions) are prepared after the teacher analyses the material that has } \\
\text { been submitted }\end{array}$ & 40 & 89 & 5 & 11 \\
\hline 8 & Make a question lattice first before the question is assembled (made) & 37 & 82 & 8 & 18 \\
\hline 9 & The question grid must reflect what competencies students must possess & 40 & 89 & 5 & 11 \\
\hline 10 & Questions are made based on the wishes of the teacher who teaches in the class & 25 & 55 & 20 & 45 \\
\hline 11 & Prepare skills assessment instruments that will be used for one semester & 34 & 76 & 11 & 16 \\
\hline & Average & & 84 & & 16 \\
\hline
\end{tabular}

\section{Statement 5 Prepare a list of names of students in each class}

Against this statement, 40 teachers (89\%) prepared a list of names of students in each class. While as many as five teachers $(11 \%)$ did not prepare a list of names of students in each class. This shows that the management of teacher assessment at the planning stage is carried out as evidenced by the preparation of a list of students' names in each class.

\section{Statement 6 Prepare an attitude assessment instrument that will be used for one semester}

From the results of the study obtained data that as many as 40 teachers $(89 \%)$ teachers prepared an attitude assessment instrument that will be used for one semester / While as many as five teachers (11\%) did not prepare an attitude assessment that will be used for one semester. This means that the management of assessments carried out by teachers related to the preparation of attitude assessment instruments has been implemented.

Statement 7 Knowledge assessment instruments (questions) are prepared after the teacher analyses the material that has been submitted

Of the 45 teachers studied, it was found that as many as 40 teachers $(89 \%)$, the teachers prepared the knowledge assessment instrument (problem) by previously analysing the material presented. While the teacher's knowledge assessment instrument did not prepare as many as five teachers $(11 \%)$ by conducting material analysis first.
Statement 8 Make a grid of questions before the problem is assembled (made)

The teachers who make the grid before making assembly questions are 37 teachers (82\%). While the teachers who did not make the question boxes before assembling them were eight teachers $(18 \%)$. This means that the management of the teacher's assessment in making the question box has already begun (carried out by PPKn students).

\section{Statement 9 The question grid must reflect what competencies students must possess}

From the data that has been obtained shows that 40 teachers $(89 \%)$ they prepare a lattice of questions that reflect what competencies students must possess. While as many as five teachers $(11 \%)$ did not make or make a grid that reflects what competencies students must possess. This means that the data shows that the teacher's assessment management at this stage has been carried out by some teachers.

Statement 10 The question is made based on the wishes of the teacher teaching in the class

From the data obtained it is known that as many as 25 teachers (55\%) were made based on the teacher's wishes. While as many as 20 teachers (45\%) were made not based on the teacher's wishes. The correct question is made not based on the teacher's wishes alone but is made based on the prepared grid. The grid is made based on the material that has been submitted. In this context man. Teacher assessment is considered to have not been implemented. 


\section{Statement 11 Prepare a skill assessment instrument that will be used for one semester}

From the research data obtained that some 34 teachers $(76 \%)$ teachers prepare a skill assessment instrument that will be used for one semester.
Meanwhile, a total of 11 teachers (24\%) teachers did not prepare skill instruments that will be used for one semester. This shows that in the context of preparing instruments for assessing management skills, teacher assessment has been carried out.

Table 3

Assessment Implementation

\begin{tabular}{|c|c|c|c|c|c|}
\hline \multirow[t]{2}{*}{ No } & \multirow[t]{2}{*}{ Statements } & \multicolumn{2}{|c|}{ Do } & \multicolumn{2}{|c|}{$\begin{array}{c}\text { Are not } \\
\text { done }\end{array}$} \\
\hline & & f & $\%$ & $\mathbf{f}$ & $\%$ \\
\hline 12 & When learning to conduct an attitude assessment in accordance with a predetermined plan & 39 & 87 & 6 & 13 \\
\hline 13 & Assessment of attitudes using prepared attitude instruments & 45 & 100 & - & - \\
\hline 14 & Conduct knowledge assessment in accordance with predetermined planning & 45 & 100 & - & - \\
\hline 15 & Knowledge assessment uses pre-prepared questions & 40 & 89 & 5 & 11 \\
\hline 16 & Conduct skills assessments in accordance with predetermined planning & 43 & 96 & 2 & 4 \\
\hline 17 & Skill assessment uses a skill assessment instrument that has been prepared & 43 & 96 & 2 & 4 \\
\hline & Average & & 81 & & 19 \\
\hline
\end{tabular}

Regarding the assessment, management carried out by the teachers during the implementation of the evaluation as described in the table above shows that most teachers conduct appraisal management when evaluating well (Table 3). This can be seen in a large number of teachers who answered the choice compared to those who answered it was not done. This can be explained as described below:

Statement 12 When learning to conduct an attitude assessment in accordance with a predetermined plan

Attitude assessment can be done by the PPKn teacher when learning takes place (in the classroom) or outside the classroom. The teacher who answered the attitude assessment was carried out when the learning took place as many as 39 teachers $(87 \%)$, while the teacher who answered was not carried out an attitude assessment when learning took place as many as six teachers $(13 \%)$.

Attitude assessment can be done by PPKn teachers both when learning in class and outside the classroom. The number of teachers who conduct attitude assessments during learning shows that the teacher has conducted assessment management. Even so for teachers who do not conduct an attitude assessment when learning takes place also does not matter.

\section{Statement 13 Assessment of attitudes using prepared attitude instruments}

For this statement, all 45 teachers $(100 \%)$ studied stated that when evaluating the attitudes of teachers using prepared attitude instruments. This means that the teachers have implemented assessment management at this stage of implementation. Do not let the teacher have prepared an attitude instrument, but the teacher does not use it.

\section{Statement 14 Conduct knowledge assessment in accordance with predetermined planning}

From the data mentioned above shows that all teachers studied 45 teachers $(100 \%)$ use knowledge assessment in accordance with the predetermined planning. This means that the teachers have conducted knowledge assessments in accordance with the predetermined planning.

\section{Statement 15 Assessment of knowledge using pre- prepared questions}

From the data as mentioned above 40 teachers $(89 \%)$ assessed knowledge using pre-prepared questions. While as many as five teachers (11\%) did not use the knowledge assessment that had been prepared. This means that the management of teacher assessment has been carried out because the teacher uses knowledge assessment of the prepared questions.

\section{Statement 16 Conduct skills assessments in accordance with predetermined planning}

The results showed that as many as 43 teachers $(96 \%)$ had conducted skills assessment in accordance with the predetermined planning. Meanwhile, as many as two teachers (4\%) did not conduct skills assessments in accordance with the prescribed plans. This means that the teachers have carried out assessment management.

\section{Statement 17 Statement of skill assessment using a skill assessment instrument that has been prepared}

From the data above shows that as many as 43 teachers (96\%) assessments of skills conducted by the teacher using instruments that have been prepared in advance. While two teachers $(4 \%)$ did not use the prepared attitude assessment instrument. This means that the teachers have carried out assessment management because the teacher uses a skill assessment instrument from a previously prepared instrument.

Score processing showing the Table 4.

Statement 18 Performing a score (correction) of the attitude assessment that has been done

From the data above as many as 31 teachers $(69 \%)$ did a scoring assessment of the attitudes that had 
been done, while as many as 14 teachers (31\%) did not score attitude assessment. The data shows that most of the teachers have taken assessment management measures, especially at the value processing stage.

\section{Statement 19 Includes a score of assessment of attitudes, knowledge, and skills into prepared formats}

From the data above 44 teachers (98\%) included scores on the assessment of attitudes, knowledge, and skills into prepared formats and one teacher $(2 \%)$ did not include scores on attitudes, knowledge, and skills assessment into formats which has been prepared. This data shows that most PPKn teachers $(98 \%)$ have conducted appraisal management well because they include assessment scores on attitudes, knowledge, and skills in the prepared formats.

\section{Statement 20 Performs a score (correction) of the assessment of skills that have been carried out}

From the data above there are 40 teachers (89\%) doing scoring (correction) on the assessment of skills that have been done. While as many as five teachers $(11 \%)$ did not carry out corrections to the assessment of skills that had been done. Appraisal management is when the results of the assessment of skills that have been done are scoring (correction).

Table 4

Score Processing

\begin{tabular}{|c|c|c|c|c|c|}
\hline \multirow[t]{2}{*}{ No } & \multirow[t]{2}{*}{ Statement } & \multicolumn{2}{|c|}{ Do } & \multicolumn{2}{|c|}{$\begin{array}{l}\text { Are not } \\
\text { done }\end{array}$} \\
\hline & & f & $\%$ & $\mathbf{f}$ & $\%$ \\
\hline 18 & Performing a score (correction) of the attitude assessment that has been done & 31 & 69 & 14 & 31 \\
\hline 19 & Includes a score of assessment of attitudes, knowledge, and skills into prepared formats & 44 & 98 & 1 & 2 \\
\hline 20 & Performs a score (correction) of the assessment of skills that have been carried out & 40 & 89 & 5 & 11 \\
\hline 21 & Enter score of attitudes, knowledge and skills into prepared formats & 40 & 89 & 5 & 11 \\
\hline 22 & Analyze attitudes assessment scores to be attitudinal values & 30 & 67 & 15 & 33 \\
\hline 23 & Perform an analysis of the score of knowledge assessment into a value of knowledge & 40 & 89 & 5 & 11 \\
\hline 24 & Analyze skills assessment scores into skill scores & 28 & 62 & 17 & 38 \\
\hline 25 & Enter the values of attitudes, knowledge, and skills in the prepared assessment format & 40 & 89 & 5 & 11 \\
\hline & Average & & 72 & & 28 \\
\hline
\end{tabular}

Statement 21 Enter score of attitudes, knowledge and skills into prepared formats

From the results of the research that has been obtained it is known that as many as 40 teachers (89\%) included scores of assessment of attitudes, knowledge, and skills into the prepared formats. While as many as five teachers $(11 \%)$ did not include scores for assessing attitudes, knowledge, and skills in the prepared formats. From these data shows that teacher assessment management has been carried out.

\section{Statement 22 Analyze attitudes assessment scores} to be attitudinal values

The results showed that as many as 30 teachers $(67 \%)$ analysed attitude assessment scores into attitudes. While 15 teachers $(33 \%)$ did not analyse assessment scores to be attitudinal values. This means that most of the teachers have conducted appraisal management well because they have analysed the attitude assessment scores to be attitudinal values.

\section{Statement 23 Perform an analysis of the score of knowledge assessment into a value of knowledge}

From the results of the study showed that 40 teachers $(89 \%)$ analysed the scores of knowledge assessment into knowledge. While as many as five teachers $(11 \%)$ teachers did not analyse the scores of knowledge assessment into knowledge values. This shows that the teachers have carried out assessment management.
Statement 24 Analyze skills assessment scores into skill scores

From the research that has been done as many as 28 teachers (62\%) analysed the skills assessment scores into skill scores and as many as 17 teachers (38\%) did not analyse the skills assessment scores into skill scores.

Statement 25 Enter the values of attitudes, knowledge, and skills in the prepared assessment format

The results showed that as many as 40 teachers $(89 \%)$ had included the values of attitudes, knowledge, and skills in the prepared assessment format. While five teachers $(11 \%)$ did not include the values of attitudes, knowledge, and skills in the prepared format.

\section{DISCUSSION}

From the teacher's perspective, the results of the monitoring and evaluation show that the teacher has difficulty with attitudes assessment. Especially in self-assessment, colleagues and journals. The response of the principal associated with the 2013 curriculum is the lack of students' books. Difficulties in obtaining sources of information related to the 2013 curriculum, however, the school principal still wants to implement the 2013 curriculum. Meanwhile, supervisors respond that the 2013 curriculum requires supervisors to listen. 
Another relevant study is that what Anshori has done shows that teachers experience difficulties in making lesson plans, similar research conducted by Rusilowati (2013) says that teachers have the problem in learning following the 2013 curriculum, which is only $66 \%$. Likewise, the teacher's assessment of difficulties in understanding $87 \%$ of the methods of assessment, difficulties in making $66 \%$ observation instruments and making other instruments $79 \%$.

A similar study carried out by Suroso (2013) stated that in good ideas, but from the implementation side the teachers had difficulties. Along with the lack of facilities and infrastructure that schools have, it is increasingly difficult for the implementation of the 2013 curriculum. Darmaningtyas's research strengthened previous researchers that teachers experienced difficulties with integrated subjects that were originally based. Likewise, the difficulty in assessing qualitative, while the final assessment still uses the National Examination (Puskurbuk, 2015).

However, the assessment of students is a must by teachers, including PPKn teachers. The variety of assessment instruments certainly provides additional tasks that must be done by the teacher in assessing students. The teacher feels confused with various types of assessment instruments that must be done by the teacher. As a result, the teacher is not evaluating the students by using these instruments, but instead, these instruments are ignored and the assessment is only done based on the teacher's wishes without seeing the real reality. It is essential to see how to manage (manage) attitudes, knowledge and skills.

\section{CONCLUSION}

From the results of the research and discussion above, it can be concluded that PPKn teachers who were sampled in this study (45 teachers) have conducted their assessment management. This can be seen from the high frequency (number of teachers) who answered the statement of conducting assessment activities both during planning, implementation and processing of value.

At the time of planning, $81 \%$ of teachers carried out appraisal management well, as well as during the assessment, $81 \%$ of teachers carried out assessment management well. Likewise when processing value as much as $72 \%$ of teachers also carry out assessment management well. Thus the teachers have conducted appraisal management, both at the time of planning, implementing, and processing value, although there are still teachers who have not implemented assessment management.

Several suggestions need to be followed up as follows: (1) the scope of the research is still too small so that the results of this study have not ensured that all teachers have carried out assessment management both at the planning, implementation and value processing stages; and (2) further research is needed with a large number of samples and from several other subject teachers, as well as a more different instrument variation.

\section{REFERENCES}

[1] Bungin, B. 2001. Metodologi Penelitian. Surabaya: Airlangga University Press.

[2] Daryono. 2011. Pengantar Pendidikan Pancasila \& Kewarganegaraan. Jakarta: Rineka Cipta.

[3] Depdiknas. 2003. Standar Kompetensi Bahan Kajian; Pelayanan Profesional Kurikulum Berbasis Kompetensi. Jakarta: Puskur Balitbang.

[4] Depdiknas. 2003. Kurikulum Berbasis Kompetensi: Pelayanan Profesional Kurikulum Berbasis Kompetensi. Jakarta: Puskur Balitbang.

[5] Depdiknas. 2003. Pengelolaan Kurikulum di Tingkat Sekolah: Pelayanan Profesional Kurikulum Berbasis Kompetensi. Jakarta: Puskur Balitbang.

[6] Depdiknas. 2003. Penilaian Kelas: Pelayanan Profesional Kurikulum Berbasis Kompetensi. Jakarta: Puskur Balitbang.

[7] Depdiknas. 2013. Naskah Uji Publik Kurikulum 2013. Jakarta: Puskur Balitbang.

[8] Depdiknas.2015. Evaluasi Pelaksanaan Penerapan Kurikulum 2013. Jakarta: Puskur Balitbang.

[9] Dojowarsito, P. 1974. Kamus Lengkap IndonesiaInggris. Jakarta: Hasta.

[10] Handoko, T. 1984. Manajemen. Yogyakarta: BPFE.

[11] Laura, K. A. 2016. Psikologi Umum: Sebuah Pandangan Apresiatif. Jakarta: Salemba.

[12] Linn, R. I., and Gronlund, N. E. 1995. Measurenment and Assessment in Teaching. New Jersey: Prentice Hall.

[13] Made Pidarta,1989. Manajemen Pendidikan Islam, Cet. 1, Jakarta: Bina Aksara.

[14] Mulyono. 2008. Manajemen Administrasi dan Organisasi Pendidikan. Yogyakarta, Ar-Ruzz Media.

[15] Nitko, A. J. 1996. Educational Assessment of Student. New Jersey: Prentice Hall.

[16] Popham, W. J. 1995. Classroom Assesssment: What Teacher Need to Know. Los Angeles: Allyn and Bacon.

[17] Putra, N. 2013. Penelitian Kualitatif IPS. Bandung : PT Remaja Rosdakarya.

[18] Uno, H. B. 2014. Assessment Pembelajaran. Jakarta: Bumi Aksara.

[19] Sugiyono. 2012. Metode Penelitian Pendidikan. Bandung: Alfabeta.

[20] Sukmadinata, N. S. 1997. Pengembangan Kurikulum: Teori dan Praktek. Bandung: PT Remaja Rosdakarya.

[21] Sulistiyorini. 2006. Manajemen Pendidikan Islam. Surabaya: eLKAF.

[22] Sumarsono. 2006. Pendidikan Kewarganegaraan. Jakarta: Gramedia Pustaka Utama.

[23] Syafaruddin. 2005. Manajemen Lembaga Pendidikan Islam. Jakarta: Ciputat Press.

[24] Warsito. 2012. Pendidikan Pancasila Era Reformasi. Yogyakarta: Ombak.

[25] Undang-undang Nomor 20 tahun 2003 tentang Sistem Pendidikan Nasional. 2003: Jakarta: Ministry of Education and Culture. 